\title{
Speaking denunciation: satire as confrontation language in contemporary Nigerian poetry
}

\author{
Niyi Akingbe \\ Department of English and Literary Studies, Federal University Oye-Ekiti, Nigeria
}

\begin{abstract}
Contemporary Nigerian poets have had to contend with the social and political problems besetting Nigeria's landscape by using satire as a suitable medium, to distil the presentation and portrayal of these social malaises in their linguistic disposition. Arguably, contemporary Nigerian poets, in an attempt to criticize social ills, have unobtrusively evinced a mastery of language patterns that have made their poetry not only inviting but easy to read. This epochal approach in the crafting of poetry has significantly evoked an inimitable sense of humour which endears these poems to the readers. In this regard, the selected poems in this paper are crowded with anecdotes, the effusive use of humour, suspense and curiosity. The over-arching argument of the paper is that satire is grounded in the poetics of contemporary Nigerian poetry in order to criticize certain aspects of the social ills plaguing Nigerian society. The paper will further examine how satire articulates social issues in the works of contemporary Nigerian poets, including Niyi Osundare, Tanure Ojaide, Chinweizu, Femi Fatoba, Odia Ofeimun, Ezenwa Ohaeto, Obiora Udechukwu and Ogaga Ifowodo. Viewed in the light of artistic commitment, the paper will demonstrate how satire accentuates the role of these poets as the synthesizers/conduits of social and cultural concerns of Nigerian society for which they claim to speak. As representatively exemplified in the selected poems, the paper will essentially focus on the mediation of satire for the impassioned criticism of social and moral vices, militating against Nigeria's socio-political development.
\end{abstract}

Key words: speaking denunciation, contemporary Nigerian poets, satire, mediation, confrontation language

\section{Introduction}

Satire as the act of using humour or exaggeration to speak out against society's ills, has always been related to literature. It is seen directly in literary works which satirize particular social vices, and is present in all forms of African literature. G.G Darah opines that

..."[T] he satirist is seen as a defender of communal norms and virtues." This image of the satirist has led some students of the genre to discriminate between satire proper, on the one hand, and pseudosatire or lampoon, on the other. According to this view, a lampoon is a descriptive portrait that relies on invective rather than objective and sophisticated analysis. By contrast, it is argued that satire avoids opprobrious terms and achieves its aim through what the eighteenth century English satirist, John 
Dryden, called "The fineness of a stroke that separates the head from the body, and leaves it standing in its place" (Darah, 2005, pp. 22-23).

Ngugi wa Thiong'o has also noted that "satire takes for its province a whole society, and for its purpose, criticism," he stresses further that, "the satirist sets himself certain standards and criticizes society when and where it departs from these norms. He invites us to assume his standards and share the moral indignation which moves him to pour derision and ridicule on society's failings. He corrects through painful, sometimes malicious, laughter" (wa Thiong'o, I972, p. 55). Ngugi's definition has a ringing parallel in Tejumola Olaniyan's description of satire, "The whole society being its constituency, satire focuses its lens on our failings as a community of people, and magnifies one or several of such our sores for critical inspection, using as its surgical tools such sharp weapons as scorn, derision, ridicule, bitter irony and laughter. But the appropriate set of standards - against which our failings can be determined - to form the base line of satire has often times been the point of departure between satirists and between the satirist and his critic" (Olaniyan, I988, p. 48).

Northrop Frye, in the view of Kimani Njogu, sees satire as "militant irony" that has two fundamental aspects. First, he acknowledges that aggression constitutes satire's indispensable component, satire is an attack. Second, Frye sees irony as satire's recurrent weapon (Njogu, 200I, p. 3). He further emphasizes that "Irony is itself a dialogic relation. Satirists, by utilizing irony, call on interpreters to refigure the meaning of the utterance in view of its new context of use. They expect their readers to make the necessary external connections. Satire is dialogic in at least two senses: first, it makes reference to another text that is the subject of critique. Second, it depends on the audience to read it as satire" (Njogu, 200I, p.3). Consequently, Njogu has fittingly established a correspondence between satire and parody, when he claims "satire, like parody, is linked to the carnival sense of the world. In both genres, the world is turned inside out [...] because satire depends principally on the interpreters' ability to recognize that the oblique surreptitious expression is actually an attack with certain goals, it is an ambivalent genre" (Njogu, 200I, p. 3).

Due to the manner of its emergence against the background of European colonialism, satire has always been present to a significant extent in Nigerian literature. Even during the colonial era, leaders of nationalist and independence movements used literature to satirize the injustice of foreign domination and exploitation. Thus, individuals such as Nnamdi Azikiwe, Dennis Osadebey, and others, used literary expressions couched in satire to advocate essentially political ideas. Their themes often centred upon the historical greatness of Nigeria and the way in which colonial rule had debilitated it.

This paper's overarching focus is on how satire is used in contemporary Nigerian poetry in order to criticize the prevailing social ills such as corruption, the African dependency syndrome, deception of hapless parishioners by the clergy and the influence of the military on Nigeria's politics. The paper is grounded in the manipulation of the interstice between art/tradition and social engagement by contemporary Nigerian poets. This social criticism is taking place by borrowing artistic elements from traditional African cul- 
ture, such as proverbs, orature, aphorism and anecdote. The paper will thus examine how the selected poets in this paper, in an attempt to criticize social ills through satire, tend to borrow from "the rich African verbal art forms to create new visions of life and new poetic idioms with remarkable originality. These borrowings occur in the form of the imaginative use of African traditional symbols, images, proverbs, myths and other traditional stylistic devices" (Bodunde, I992, p. 25). Importantly, the paper will evaluatefurther both the formal and content-related elements of satire in the contemporary Nigerian poetry.

\section{Contextualising satire in contemporary Nigerian poetry}

In his examination of the rhetoric of philosophy, Jacques Derrida emphasizes the corresponding significance of writing to speech. In his deconstructive project, the term 'writing' is explicated not simply to mean the graphic notation of language, but to include the unpleasant nuances of language that are derived from an intricate historicalintertexual process within which an utterance or a text is situated. Derrida's idea underscores the prioritization of speech as the bedrock of meaning. The vibrant element in Derrida's postulation on language is a feature termed 'differance'. In Derrida's view (I973), 'differance' is perceived not so much as a word or a concept but as "the strategic note or connection... which indicates the closure of "presence". Put another way, "differance" implies the lack of immediate and total accessibility to meaning due to the fact that language is grounded in a canny and interminable interplay of deferral and difference.

Derrida's deconstructive focus is of significant importance to the evaluation of satire as the mode of communication in the poetry of the Nigerian contemporary poets, and will be used in the analysis of the poetry of Femi Fatoba, Odia Ofeimun, Tanure Ojaide, Obiora Udechukwu, Niyi Osundare, Chinweizu, Ezenwa Ohaeto and Ogaga Ifowodo. Deconstruction theory sees meaning as a continuous process in a literary engagement. It does not assume that a poem has a "harmonious equilibrium" but rather, that it always take cognisance of what Derrida calls a "violent hierarchy" (Derrida, I972, p. I46). This is what imbues a poem with the capacity to evince multiple, albeit conflicting interpretations and meanings, otherwise known as the 'aporia'. Consequently, for the deconstructionist, there is always an interplay of two forces in a literary work, a situation which has given impetus to the term "dangerous supplement" (Derrida, I973). This development will always orchestrate instability among the signifiers, thereby upsetting the meaning of even a traditionally tidy and unambiguous reading.

This paper will examine the relationship between a word/concept and its multiple and conflicting interpretations in order to evaluate, how "English in the recent Nigerian poetic articulation is stretched in such a way as to approach the linguistic mediation of the poet's mother tongue, which at any rate shares some affinity with the flavour of the other local languages" (Nwachukwu-Agbada, I99I, p. I66). The choice of the poems in this paper is premised on the fact that, almost all the poems have similar features. They deal with socio-political issues besetting Nigeria's nationhood, and are marked by the realization that, decades after the nation's independence, social ills are on the increase, ills that include poverty, corruption, military rule, adversarial economic linkage with the extended family, and the clergy's exploitation of parishioners . 


\section{Satire in Nigerian literature: a historical survey}

Ethnic groupings and nationalities in present day Nigeria have robust traditions of literature that stretch back to before the historic Arabic and European cultural disruption of these literary traditions. The incursions of these alien cultures and civilizations into Nigeria and the West African sub-region in the eighteenth and early nineteenth centuries, destructively undermined the literary productions by subordinating indigenous religious thoughts and traditional philosophies. G.G Darah has significantly captured the consequence of these incursions in his paper entitled, "Literary Development in Nigeria":

Today, most of these traditions, like the human communities that created them, have declined. This state of cultural depression is a consequence of the conquest of Nigeria by British colonialism in collaboration with christian and Islamic religions. The dominant and the most devastating force was, of course, the subordination of Nigeria's economic interests to that of imperial Britain. The consequent devaluation of indigenous cultures and the imposition of colonial ideological hegemony took some time to accomplish. The creation of an educated elite was part of this programme of cultural disorientation. This elite is credited with the inauguration of a written tradition of literature which colonialist criticism erroneously takes as the genesis of literature in Nigeria. (Darah, 1988, p.1).

Although the earliest forms of literary productions among these groups were conducted largely through orality and orature, literature in contemporary Nigeria is significantly rendered in a written form. Ernest Emenyonu fittingly articulates this very important role of orature in the formation of Nigerian literature in a paper entitled "The Rise and Development Of Igbo Literature", when he argues that, "Nigerian literature as a discipline has three significant and historically crucial stages namely: the oral literature, literature written in indigenous languages, and literature written in non-Nigerian Languages. A study of the development of Nigerian literature must follow that chronological sequence to be meaningful. Literature as an artistic expression is a cultural activity, oral literature is, therefore, the absolute foundation of Nigerian literature" (Emenyonu, I988, p. 34).

However, Nigerian intellectuals began writing in English in the nineteenth century and the process was well established by the early twentieth century. It would be impossible not to acknowledge this epoch of written literature, the long-term effect of which is described by Gareth Griffiths: "Africans owned and ran newspapers and printing houses during the nineteenth and early twentieth centuries in Sierra Leone, Ghana and Nigeria. This has continued into the present day, with newspapers still acting as a conduit for the publication of literature and literary criticism" (Griffiths, 2000, p. I). Some of these newspapers, such as The Anglo-African, The Lagos Observer, Lagos Standard and Lagos Weekly Record had their bases in Lagos, Nigeria. Nevertheless, earlier Nigerian writers using English appropriated the colonial language of English and used it to their own ends by manipulating the vocabulary of dissent inherent in the English language, to articulate a satiric condemnation of European merchants' exploitation of the colonies' agricultural produce ; and by so doing express the struggle for self-determination and for self- 
identity. To varying degrees, satire in the earliest forms of writing by Nigerian writers was grounded in the moral overtones and socio-political themes of anti-colonial struggles. But the languages of expression in most of these early literary works were the indigenous Nigerian languages of Yoruba, Igbo and Hausa.

\section{Satire in indigenous Nigerian languages}

Satire was given a boost in the Yoruba literary production, as exemplified by the literary oeuvre of Daniel Olorunfemi Fagunwa: Ogboju Ode Ninu Igbo Irunmole (I939); Igbo Olodumare (I949); Ireke Onibudo (I949); Irinkerindo Ninu Igbo Elegbeje (I954) and Adiitu Olodumare (I96I). A discernible theme that runs across these titles is fundamentally predicated on didacticism. In these novels, Fagunwa satirizes greed, gluttony, impatience, anger and avarice. Fagunwa is unusual among Yoruba writers in his unflagging commitment to the promotion of Yoruba's linguistic and aesthetic proclivity. A Yoruba literary critic, Afolabi Olabimtan commended this commitment in a paper entitled "Daniel Fagunwa", in which he succinctly remarks that "But it is as a novelist that Fagunwa won the prime of place among the writers of his time. By his use of beautiful expressions and his vivid descriptions of events and places, by his ability to blend romance with realism nicely, and by his use of both traditional materials and borrowed elements with outstanding success in his novels, he towers above all creative writers in Yoruba before him, and wins for himself an eminent position among all Yoruba writers" (Olabimtan,I988, p. I4).

Fagunwa uses the spirit and the supernatural motifs rooted in the Yoruba oral narratives as exemplified in Ogboju Ode Ninu Igbo Irunmole (I939); Ireke Onibudo (I949) and Irinkerindo Ninu Igbo Elegbeje (I954), to criticize societal ills in Yoruba territory. The pioneering effort of Daniel Fagunwa in Yoruba literature was correspondingly complemented by the quintessential theatrical performances of Hubert Ogunde, whose imaginative combination of the choreographic and musical resources of sacred church drama was used to provocatively criticize and repudiate the British colonial authority's high handedness in its dealings with the Nigerian workers. The abuse of power by the British colonial authority is wittily satirized in Ogunde's scathing dramatic productions: Strike and Hunger (I945); Tiger's Empire (I946); Herbert Macaulay (I946); Towards Liberty (I947) and Bread and Bullets (I950), a vitriolic denunciation of the killings of 2I Enugu coal miners by the repressive British police, at Iva Valley in November, I949 (Darah, I988, p. 5).

The towering father figure image of Pita Nwana in Igbo literary production has been attested to by his novel, Omenuko (I933). The novel lampoons the dramatic crime committed against the community by the eponymous hero, Omenuko, when he sells sons of his relations and neighbours into slavery and uses the proceeds to strengthen his enterprise. The renowned Igbo literary critic, Ernest Emenyonu, commented on Pita Nwana's dexterity at exploiting cultural materials in the denunciation of social vices among eastern Nigeria's Igbo people in a paper entitled "Pita Nwana". In this paper, he enthuses that, "Pita Nwana" is a writer with many attributes including imaginative use of language, wit, volatile humour, incisive irony and a well-constructed and skillfully handled plot. But his distinction as an author mainly lies in his unique ability at characterization. Thus 
in Omenuko he concentrates on the development of the hero, creating thereby one of the most memorable characters a reader can encounter in fiction" (Emenyonu, I988, p. I0). In Omenuko, Pita Nwana satirizes man's obsessive craving for material possessions to the detriment of the well-being of his society.

Satire in Hausa literary production is shaped by the dynamics of cultural practices in Northern Nigeria, especially the notion of cultural change that results in the significant alteration of fundamental cultural practices relating to marriage, family, individual social status and the colonial administration and its operations in northern Nigeria. Prominent among the Hausa writers whose literary works satirize social upheavals in northern Nigeria are Mu'azu Hadeja,Akolu Aliyu, Sa'adu Zungur, Aliyu Na-Mangi and Aminu Kano (Yahaya, I988:I0-2I). Although Aliyu Na-Mangi is a blind poet, his literary prowess is showcased in the prodigious Wakar Infiraji, a narrative in twelve books which discusses Hausa society in terms of social and political transitions. But Sa'ad Zungur is perhaps the most radical of the indigenous Hausa writers: "In his numerous pamphlets and poems, he advocated the revolutionary defeat of the feudalist and reactionary oligarchy represented by the Northern Peoples' Congress (NPC)" (Darah, I988, p. 4). Also Aminu Kano's Wakar Zamani (The Song Of Modernity) (n.d), reflects on the emerging societal developments with its attendant challenges. This is unambiguously portrayed in Wakar Yanci, a stanza in Wakar Zamani, which tasks the young men to live up to their society's expectations (Yahaya, I988, p. 89). In the works of these writers, satire constitutes a prominent literary weapon deployed against the excesses of the oligarchy of northern Nigeria, and outright criticism of the oppressive British colonial administration.

\section{Satire in pre-independence Nigerian literature in English}

From the early nineteenth century to the early twentieth century, the West African sub-region witnessed interventions by European cultures. It was during this period that countries such as Liberia and Sierra Leone were established, and the writers and intellectuals produced by these two countries constitute the bastion of intense anti-colonial agitation in the sub-region. It is also a period in which the sub-region experienced a flourishing of literary production from Liberia to Nigeria. J.E Casely Hayford's Ethiopia Unbound (I9II), although written as a fiction, is undoubtedly an autobiographical work which criticizes European exploitation of colonial West Africa, and stridently advocated for the Africans' to take control of their own affairs.

Rev. Samuel Johnson's The History of the Yorubas satirized the stereotypical misconception of the African cultural practices by the Europeans. In the view of Gareth Griffiths, Samuel Johnson's intellectual contribution to West African literary production reverberates in his ability to "construct powerful defences of traditional practices, and rebutted the garish and denigratory colonial narratives of traditional African societies, which emphasized indiscriminate human sacrifice, mass cannibalism, and other horrors with which the invaders had justified their political and military incursions into the interior of the kingdoms of Ashanti and Benin" (Griffiths, 2000, p. 29). Kobina Sekyi's The Blinkards (n.d), but produced in I9I5 by members of the Cosmopolitan Club in Cape Coast, is a play 
which satirized the tendency of the Gold Coast's 'intellectuals' to denigrate their own customs and promote European habits to the detriment of the African cultural practices. Correspondingly, in this mould, is R.E Obeng's Eighteenpence (I943) which satirizes the clashes between African and European cultures, a critique that is reminiscent of Chinua Achebe's backlash against the European's cultural hegemony in Things Fall Apart (I958).

Prior to Nigerian independence in I960, literary production in English in the country dealt with the thematic concerns of corruption of urban life, criticism of the colonial authorities and the denigration of African culture by the European culture. These themes are vividly portrayed in Cyprian Ekwensi's People of the City (1954) which decries the racy and reckless lifestyles of the urban African city dwellers in sharp contrast with the pervading serenity, characteristic of the African socio-cultural milieu. While T.M Aluko's One Man, One Wife (I959) satirizes the overzealousness and hypocrisy of Christian values in colonial Nigeria, Chinua Achebe's Things Fall Apart (1958) satirizes the European's intolerance, and ignorance of African (cultural) value systems. The thematic preoccupation of Things Fall Apart has a striking parallelism in James Ene Henshaw's This is Our Chance (I945), a play which satirizes the palpable tension between the African cultural exegesis and the European's cultural world view. The tradition of satire was further engrained into the wood of Nigerian literature by the "Onitsha Market Literature" between 1947 and I966. This literary tradition refers to an ambitious attempt by the largely semi-literate Onitsha market town writers to publish pamphlets, books and short-stories by local presses in the Ig6os. This literary enterprise earned its reputation from the following features: a quaint theme of simplified conflict between African tradition and European culture, a whimsical romantic invocation of rural piety, simplicity of language, brevity of form and its attractively low price. Of the 70 plus authors who featured in this tradition, the most prolific were Orlando Iguh, O.A Ogali, O. Olisa, and F.N Stephen. It is noteworthy that, except for Cyprian Ekwensi with his When Love Whispers (I948), Ikolo the Wrestler (I947) and The Leopard's Claw (I947), no other Nigerian writer of note emerged from the Onitsha market literature tradition (Darah, ı988: 6).

\section{Satire in post-independent Nigerian literature in English}

After Nigerian independence in I960, satire did not die out in the country's literature but found new causes to espouse. One of the most prominent of these was the way in which the new indigenous leaders failed to realize the lofty ideals of the independence movement, issues which were expressed in such novels as T.M. Aluko's Chief, The Honourable Minister (I970), Wole Soyinka's The Interpreters (I965), and Chinua Achebe's A Man of the People (ig66). There were also plays such as Soyinka's The Jero Plays (ig63) and Ola Rotimi's The Gods are Not to Blame (I97I). In works such as these, the failures, foibles and shortcomings of the country's leaders were portrayed in detail.

For most literary works during this era, however, satire was somewhat implicit, since it was often indirect in its criticism and usually a-specific. In other words, satire was inherent in the depiction of negative social situations rather than explicitly stated in such literary works. Yet, the fact that Nigerian authors were beginning to point out the flaws 
in their society so early in the life of their nation shows the way in which satire is virtually inherent in literature in general and fiction in particular. As the country's social, political and economic problems became more pronounced, the nature of satire within Nigerian literature became harsher and more explicit, a development that was facilitated by the increasing popularity of Marxist ideology among younger writers, particularly those of the second and third generations of Nigerian literature. Instead of merely portraying inadequacies and shortcomings, many literary artists began to advocate viable alternatives to the situations they depicted in their works.

Thus, writers including Kole Omotoso, Femi Osofisan, Tunde Fatunde and Festus Iyayi, among others, began to produce works which satirized social injustice and advocated radical social change. This meant that they not only portrayed negative social, political and economic conditions like their "non-ideological" predecessors, they also sought to show explicitly how such negative situations stemmed from an inherently flawed, unjust and unsustainable economic system inherent in capitalism; and how the only way out was the destruction of capitalism and its replacement by a socialist oriented system of governance that would guarantee the fair and equitable distribution of resources and opportunities to every member of their society, regardless of gender, age, ethnicity or status.

The emergence of Marxist and socialist ideologies in Nigerian literature was accompanied by a strengthened form of satire in which the writers targeted particular aspects of the Nigerian condition. The campaign against gender-based discrimination, for example, became more prominent as writers like Flora Nwapa, Buchi Emecheta, Karen King-Aribisala, Akachi Adimora-Ezeigbo, Zaynab Alkali and Ifeoma Okoye produced works of fiction in which this issue was focused upon. Hitherto untreated topics like environmental degradation also began to receive consideration in the works of writers like Tanure Ojaide, Niyi Osundare, Ken Saro-Wiwa, Lyndon Barret, Ebinyo Ogbowei as well as more-established writers like Wole Soyinka, John Pepper Clark-Ambekederemo and Ola Rotimi.

Over time, satire came to be seen as a useful yardstick for measuring the seriousness of the average Nigerian writer and assessing the depth of his commitment to progressive social, political and economic change. Writers who did not espouse radical ideologies were often unfairly dismissed as pro-establishment writers who did not wish to disrupt the status quo. Achebe and Soyinka, in particular, have been constantly seen in this light by many of their successors, such as Femi Osofisan, Chinweizu, Olu Obafemi and Niyi Osundare (Akingbe, 20II, p. 247). Some, like Osofisan, have even produced literary works that directly contradict the perceived positions of their predecessors, for example in No More the Wasted Breed (Ig82) he caustically responds to Soyinka's The Strong Breed (Ig63). From the perspective of satire, what this meant was that satire was gradually coming into its own as an important aspect of literary production and criticism in Nigerian literature. It was no longer satisfactory for it to be merely implicitly encoded into literary works: it was now expected that it would be overt and explicit, and would be used to judge the overall success of the selected poems in this paper. 
In the remainder of this paper, I will analyze satire in contemporary Nigerian poetry from two angles: I am first going to deal with some formal elements such as orature, proverbs and aphorism employed by the poets to bring satire into practice. Second, I will be discussing an engagement of satire by addressing the following topics: the dependency syndrome in contemporary Nigeria, the military in contemporary Nigerian poetry, the exploitation of the hapless parishioners by the clergy, criticizing moral vices in contemporary Nigerian poetry and exile as a scourge in contemporary Nigerian poetry.

\section{Foregrounding orature in contemporary Nigerian poetry}

Orature is a piece of terminology often employed in the description of the various genres of oral literature, such as proverbs, legends, short stories, traditional songs and rhymes, song-poems, historical narratives, traditional symbols, images, oral performance, myths and other traditional stylistic devices. The description of the complexity of life in contemporary Nigeria requires the deployment of poetic forms such as proverbs, anecdotes, and the fusion of literacy and orality in order to satirize social vices in Nigeria. This is discernible in the poetry of Niyi Osundare whose poetic practices "suggests that there is a contemporary phase of oral traditions existing side by side with the modern written literatures of Africa. They can still be seen and heard everywhere in Africa as vibrant forms of art" (Bamikunle, I992, p.50). This intersection between orality and modernity in the writing enterprise is significantly demonstrated in "The Prisoner's Song", a poem that utilizes the tradition of exchanging verbal insults in the Yoruba cultural milieu:

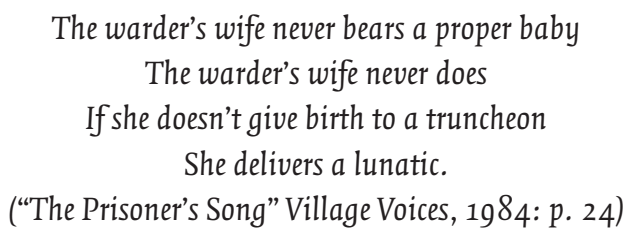

Orature in the poem is carefully chiseled out of lyricism alongside a dramatic tone, which is reinforced by its repetitive effect to satirize the image of a prison 'warder'. Derrida's 'differance' theory is fittingly employed in this poem to deconstruct the grotesque image of the warder in Yoruba folk lore. This image cuts the image of viciousness, brutality and high handedness, which is usually demonstrated in their dealings with prisoners. Pejorative symbolic imagery of the warder is grounded in objects such as 'warder's wife', 'truncheon' and 'lunatic', which eloquently reiterate the negative imagery of the warder in the Yoruba folk tradition. Orature invariably constitutes the traditional domain of Osundare, in his identification with the misery and poverty of the masses. In "Village Voices", he vows to deploy orature, to rally against the injustice and social inequity in Nigeria's political milieu: 
My words will climb the tree of wisdom

Feed multitude with fruits of thought

And plant the earth with potent seeds

(Village Voices, 1984: p. 1)

As an overarching motif in the poem, orature is intricately, elaboratively and allusively deployed as a symbol of liberation of the masses. This demonstration of artistic commitment on the part of Niyi Osundare underlies H. H. Okam's suggestion that there are clearly-discernible links between literature, history and the social environment of the society from which it emerges:

Literature is at one and the same time History's major bequest to mankind and the principal corrective of history... Because literature begins as an experience and ends as an imitation, fiction that it is, it has an edge over history. By the simplest of definitions, history is events and records of the past. As events history moves in a straight line, and even those who by their actions are said to have changed the course of history only change the direction of the line; Literature, on the other hand, gaining illumination from hindsight presents not only an imaginative reconstruct of reality but also overtly or covertly offers correctives to history by suggesting what should have been.(Okam, 1991, p. 54).

The relationship between text and society is further explained by Sanya Osha, when he posits that textual studies should not be limited to their aesthetic qualities alone. Considerable attention should also be given to the texts' sociological background in order to achieve a holistic appreciation of its meaning:

Now we may pose the question: why is it necessary for the writer to vacate the merely aesthetic space for the political sphere?... The stranglehold that African lives in is much too tenacious to allow for any kind of political complacency on the part of the writer. (Osha, 1998, p. 176).

Orature resonates as satire in Tanure Ojaide's Message of Lust, in which the poet employs the Urhobo proverbial to underscore the "antithetical juxtaposition of statements", in his criticism of the nonchalant attitude of politicians to the management of the economic resources of the country::

The fowl is guzzling corn

It knows not how much it's bought:

The woman is frying eggs

She doesn't feel the labour of the hen's anus

("Message of Lust" Children of Iroko, 1973: p. 3)

The rhythm of the poem is significantly sustained by the use of 'rhetorical proof' 
to delineate the symbolic images of profligacy and insensitivity of those Nigerian politicians who mismanage Nigeria's economic resources. Proverbs are also used rhetorically by both Ezenwa Ohaeto and Obiora Udechukwu to interrogate some perceived negative societal attitudes: "If rain wipes away footprints/Does it wipe away words?" "If a shrew smells when it is alive/What horrible odour will exude at its death?" "How many baskets of water can mould a block?" "How many he-goats can guard a yam barn?". A proverb here refers to a short sentence that people often quote, which gives advice and is often used in conversations in Africa. In the same vein, a proverbial is a sentence that is often used or is part of a popular saying. Concomitant with the language trend in contemporary Nigerian poetry, Nwachukwu-Agbada has noted that "The proverbial form is popular among the post-war poets. Being an essential accoutrement of the oral medium, the post-war poet in his love for accessibility may have found it very expedient to employ. In addition, the proverb, being a rhetorical genre, may have interested the recent Nigerian poets because of the capacity of this form to drive home populist expressions known to be the common forte of the younger poets" (Nwachukwu-Agbada, I99I, pp.I68-69). In Ezenwa Ohaeto's "Songs of a Traveller", there is also an effective use of aphorism to assess individuals' attitudes and behavioural patterns in contemporary Nigeria:

\author{
If rain wipes away footprints \\ Does it wipe away words? \\ Rather than drown in a stream \\ Let the water sweep away my cloth... \\ The Man outwitted by a snail \\ Should not be offered meat \\ If you like funeral rams \\ Why recover from sickness?
}

If a shrew smells when it is alive

What horrible odour will exude at its death?

("Song of a Madman" Songs of a Traveller, 1986: p. 16)

An aphorism is a short witty sentence which expresses a general truth or comment. Its dense use in the poem affords the poet the opportunity to question some nature induced activities which defy traditional and cultural explanations in a typical African setting. Readers familiar with the use of aphorism in the works of Osundare, Ojaide and Ezenwa Ohaeto, will find a strident parallel in the utilization of this poetic device as satire in the poetry of Obiora Udechukwu in "Omabe":

\footnotetext{
How many baskets of water can mould a block?

How many he-goats can guard a yam barn?

And we talk of yam-masters
} 


\author{
But their sons eat alibo \\ Fish that lives in the ocean \\ That same fish washes with spittle. \\ And you talk of hell \\ Does it need death to survive? \\ The question looms in the evening cloud \\ It hangs so it's now part of the sky \\ The question that questions their stools \\ (Omabe, 1978: p. 6)
}

In the poem Udechukwu manipulates a proverbial model to satirize Nigeria's wanton profligacy during its oil boom era. During this era, Nigeria was able to realize stupendous wealth from its crude oil proceeds, without recourse to 'saving for the rainy days'. The proverbial model in the poem laments the consequent effects of such wasteful spending as typified in present day Nigeria's poor health facilities, degraded education sector and the debilitating unemployment statistics which conspire to devalue Nigeria's image in the comity of nations. The trio of Osundare, Ohaeto and Udechukwu effusively makes use of the "metaphors of Nigeria" to satirize a series of Nigeria's misplaced priorities and missed opportunities as well as broken promises: the failure of the political class to provide effective governance for the nation, a deep-seated tradition of corruption among members of the ruling class and the decay in the social infrastructures. This strategy is is couched in Derrida's difference. A metaphor of Nigeria is a description of a situation (an anecdote, a vignette, an urban myth, a tale, a modern folktale) which encapsulates the essence of the Nigerian situation, especially the contradictions and paradoxes which shape it, and which, to a large extent, constitute its tragedy. It is often parable-like in content and structure, its simplicity standing in stark contrast to the complexities and absurdities that it represents. This treatment will now move on to a range of topics dealt with in contemporary Nigerian poetry.

\section{Repudiating the dependency syndrome in contemporary Nigeria}

Femi Fatoba's "Christmas Message to My Relations" is loaded with artistic humour which provides social commentary on the prevalent Nigeria's social condition regarding grinding poverty and the urgent need to circumvent it so as to maintain equilibrium in the daily struggle of earning a living:

Am gone searching for an occasional job

Because in January the renewal is due

On the insurance policy

And the vehicle licence

Of that car you all love

To ride in.

("Christmas Message to My Relations" Petals of Thought, 1984: p. 55) 
The poem satirizes the dependency syndrome in the African traditional milieu, and its inherent problematic in urban locations such as Lagos, Ibadan, Accra, Nairobi and Johannesburg where virtually every tenet of daily life has been overtly commodified. A close reading of the poem reveals the economic difficulty experienced by the persona: "...in January the renewal is due/on the insurance policy/And the vehicle licence". The poem's lamentation of insolvency broadens and deepens our understanding of the complexity of economic hardship in post-independent Nigeria, and especially, the persona's inability to cope with the economic stress and the demands of his dependents. The poem obliquely satirizes the African tradition which dictates that an individual who has reached some level of education, and has started working, is expected to use his status as a middle level worker to shoulder the financial responsibility of his younger siblings and other members of the extended family adequately. But the persona in the poem, obviously having been overburdened, decides to walk away from his apartment. He leaves a 'note' behind to explain his motive for abandoning his apartment. The note reads thus:

\section{Am gone searching for an occasional job...}

Derrida's differance theory reverberates in the personal pronoun 'I'/'I am' to illuminate an action embarked upon by the persona, and it is the task of the reader to recognize what is taking place at the moment, which plays down any direct action a reader would have expected of the persona in the poem. This action of the persona is now integrated into a declarative statement, 'Am gone searching for an occasional job'. It is interesting to note that the action of the persona is eloquently rendered through a dialogue and not in monologue. It is an action which at least implies a voice: enunciation of an intention to walk away from his economically demanding dependents.

\section{Denouncing the military in contemporary Nigerian poetry}

The recurrent military incursions into the Nigeria's political terrain and its attendant blights are inscribed in the monumental decay in infrastructures, economic pillage and devaluation of Nigeria's social norms. This has inspired a considerable number of poetry collections, mainly poems written by the contemporary Nigerian poets. These poets have experienced these devaluations at close quarters over an extended period in Nigeria's political trajectory. This experience reverberates through Oyeniyi Okunoye's view:

Proof that Nigerian poetry has been very dynamic is that it has drawn on a variety of experiences. But of the three major events that have significantly impacted on it -the Nigerian crisis of the 1960s, the Nigerian civil war (1967-70) and military rule (1966-79) and (1983-99), the impact of military dictatorship has been far more pervasive and enduring. It gave a unique identity to Nigerian poetry by assigning it a new role and redefined the social standing of the poet: it emboldened the poet, inspired a variety of poetic idioms and modified the taste of the audience. (Okunoye, 2011, p. 65). 
Nigerian poets' desire to portray the military in their poetry has much in common with that of the radical historian: to expose the military as an aberration in governance in post-colonial Nigeria, and to reveal the brutality and dehumanization of Nigerians during military rule (Okunoye, 20II, p. 76). Satire is explicitly embedded in the language of these poems as sufficiently grounded in Odia Ofeimun's The Poet Lied, to criticize the military administration's ineptitude at managing waste disposal, and enhance a clean environment:

\author{
And if you want to know why \\ The streets grunt now \\ Under rank garbage \\ Under the weight of decay, of nightsoil \\ More than ever before \\ They will point triumphantly, very triumphantly \\ At their well-made timetable: \\ "We shall get there soonest: \\ Nightsoil clearance is next on the list". \\ (The Poet Lied, 1980: p. 5)
}

A pivotal point in the poem lies in the chicanery and penchant for subterfuge on the part of Nigeria's military authority: "They will point triumphantly, very triumphantly/ At their well-made timetable". The atrociousness of the military administration, and its shoddy performance in Nigeria's political system is also overwhelmingly articulated in "The streets grunt now/Under rank garbage/Under the weight of decay, of nightsoil". The image of the military as portrayed in the poem, think again of Derrida's differance, is one generated by deception and unreliability. A further backlash against the military is acerbically deployed in Femi Fatoba's "They said I abused the Government". In this poem, one comes across an invective and a certain vitriolic exuberance which defies artistic restraint and Fatoba uses a satiric mode to write cuttingly of the government's insensitivity in relation to its corresponding devaluation of its citizens. The iconography of the widespread destruction caused by the military authority is significantly expressed in terms of craters on the roads, run-down schools and decrepit hospitals. This range of destruction is robustly indexed by Fatoba in the poem:

I asked the human tongs of Gestapo

How I did abuse the government.

Did I say the government is deaf

And does not hear the cries of her people!

Did I say the government is lame

And never lifts an arm in the service of her people!

Did I say the government is blind

And does not see where she is going!

Did I say the government is a cannibal 


\section{Killing and eating her own children! \\ Did I ever say anything \\ Bigger than the small mouth \\ With which I ask simple question? \\ Anyway, who am I to abuse the government! \\ (They Said I Abused the Government, 2001: p. 8)}

Fatoba's courage at cataloguing the tragedies of governance associated with the military in the poem should be commended, because of his employment of Derrida's differance theory, which is marked by the rambunctious humour, and abundant use of rhetoric to obliquely deride the military institution's failure to provide quality governance: "Did I say the government is lame/And never lifts an arm in the service of her people!"; "Did I say the government is blind/And does not see where she is going!". Fatoba's satirical deftness, rooted in Yoruba witticism, recalls Richard Hoggart's argument on writers' deployment of "gift of the gab" so as to appeal to the collective imagination of their readers: "...not the attitude to language of the creative writer, trying to mould words into a shape which will bear the peculiar quality of his experience, but a fluency, a "gift of the gab" and facility with thousands of stock phrases which will set the figures moving on the highly conventionalized stage of their readers' imaginations. They put into words and intensify the daydreams of their readers" (Hoggart, I957, p. 209). His recourse to this innovative path in poetic craftsmanship, underscores the paradigmatic position of contemporary Nigerian poets, in search of a form of expression that will enable them to escape strictures imposed on free expression by any repressive government.

\section{Decrying the clergy's exploitation of the hapless parishioners}

In continuation with the artistic obligation to pursue a social crusade to cleanse $\mathrm{Ni}$ geria of its social malaise, Fatoba did not spare the church, which he sees as a citadel of monumental corruption. Pastors, rather than ministering to the souls of the congregation, are rather surreptitiously preoccupied with how much they can steal from the 'offering plates'. Oyeniyi Okunoye's "Writing resistance: Dissidence and visions of healing in Nigerian poetry of the military era" (20I0) draws attention to Fatoba's sustained exploration of humour and satire in Petals OfThought (I984): "Fatoba who consolidated his position as a skilful poet in the satirical convention... Petals OfThought (I984) had earlier established his capacity for satire, revealing his skill at deploying humour and irony for satirical purposes" (Okunoye, 2010, p.72). In the poem 'Jesus Saves' Fatoba renders a gory and disturbing account of everyday harassment and pauperization of hapless Nigerians, trapped in the exploitative web of the numerous churches, mushrooming embarrassingly in the nooks and crannies of Nigeria's landscape. Fatoba touches upon three major points that now demand our urgent consideration from the perspective of the failure of the church in contemporary Nigeria: first he is concerned that the pastors have diverted away from their primary duty of preaching salvation to their congregations, being more intent on amassing wealth, thereby repudiating Christianity's popular saying that, 'this 
world is not our home'. Second, when the pastors abdicate their primary responsibilities, morals will be compromised by all and sundry in the society. Third, Fatoba believes that such willful dereliction of duty has led to a worsening of the moral crisis in the country:

From the saint and the sinner

From the robber and the robbed

From the pauper and the rich

From the fanatic and the atheist

Jesus saves at Barclays Bank

(Petals of Thought, 1984: p. 21)

The criticism of the church's exploitation of its congregations is important in the context of artistic concern deployed by Fatoba in the poem. This concern acknowledges his indebtedness to the society, which demands that writers should serve as social barometers in the exposition of wrongs in the society. Concomitant with Derrida's difference theory, language is symbolically employed in the poem to examine the 'salvation' motif of Christianity. 'Salvation' is ironically manipulated by the poet to delineate the intense desperation of the clergyman herding all and sundry to his church. "From the robber and the robbed", "From the fanatic and the atheist", "Jesus saves at Barclays Bank", constitute vibrant signifiers of the hypocrisy of 'salvation' which captures the triviality of 'spiritual masturbation' associated with the Pentecostal church's extremist credo in contemporary Nigeria. The description of the church's riotous proselytism in the poem evinces the visual quality of a movie. Further the poem sarcastically denounces the misplaced agility exhibited by the pastors and clergymen at 'fleecing' their hapless victims. This denunciation is eloquently extemporized in the following stanza:

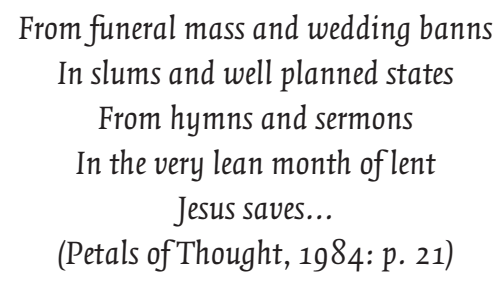

\section{Criticizing moral vices in contemporary Nigerian poetry}

Contemporary Nigerian poetry poignantly engages the focal issue of moral corruption. Consequently, the maddening urge for money and material well-being has been robustly satirized in some of these poems. In these poems, urban life is symptomatic of the devaluation of moral values, and there is a wide gulf between the rich and the poor. Frequently portrayed in these poems is a striking juxtaposition of elegant opulence against debilitating poverty, which often manifests itself in the Nigerian cities such as Lagos, Kano, Kaduna, Enugu and Port-Hacourt. For instance, in these cities, while the rich have stupendous wealth to buy comfort and luxury for themselves, the poor must 
continuously struggle, looking for the elusive jobs and with barely enough to live on. The plight of the poor, who are trapped in the throes of poverty, prostitution and alcoholism, is articulated strenuously in contemporary Nigerian poetry. This scenario is vividly captured in Chinweizu's "Faithful Mary Lou". In the poem, there is farcical treatment of a woman's unfaithfulness to her spouse. The poet satirizes hunger as the motivating factor to comment on the plight of a woman who is caught having sexual intercourse with another man. However, the woman trivializes adultery, when confronted by her husband:

\author{
Ah only slept with his name; \\ Ah only slept with his color; \\ Ah only slept with his money not with him. \\ Ah ain't been unfaithful to you, can't you see? \\ ("Faithful Mary Lou" Energy Crisis and Other Poems, 1978: p. 26)
}

The poem satirizes hunger as the scourge of human existence and a source of depravity among the downtrodden. The individual's inability to address this fundamental issue could lead to a trade-off, as demonstrated by the action of the woman in the poem, to derive much needed monetary gratification. Irony and humour in the poem underline hunger as a serious social issue. Derrida's demystificatory exegesis in relocating meaning not in immanent and immutable terms, reverberates succinctly in the tenor of the poem: the poem explores the pain and inconvenience associated with the 'hunger' of the persona, which subsequently made her to sleep with other man's 'name', 'color' and 'money', but not the personality of the man. This dislocation in the meaning of adultery affirms a reappraisal of the modernist subversion of Nigeria's social and cultural ethos by the influence of western civilization.

\title{
Exile as a scourge in contemporary Nigerian poetry
}

To imagine the concept of exile in the works of contemporary Nigerian poets, one must first come to terms with alienation so well dramatized by Lenrie Peters in his ' $\mathrm{He}$ Walks Alone'. This represents a fragmented chapter in the life of an African student whose first realization of exile evokes the concrete and evocative world of Bathurst, juxtaposed with the cold, and hostility of England's milieu - the perceived comfort and warmth of the country are so desperately desired by, but are denied to the people in exile from the colonies. Sensitivity to exile and forced emigration stokes the fires of satire in the poetics of Tanure Ojaide's When it no longer Matters where you live. The interlocking of anguish and nostalgia constitute satiric jabs articulating the pains and alienation one feels when one is forced to run away from one's own country, as experienced by Ojaide and other poets during the obnoxious military regime of General Sani Abacha, between I994 and 1999. During this period, many politicians and civilians were imprisoned. The poem laments the danger of returning to Nigeria, while Abacha's reign of terror still persists: 


\author{
There's no one so hurt at home \\ Who forgets the pain outside- \\ That's the persistent ache one carries \\ until home is safe to return to \\ when it no longer matters \\ where you choose to live! \\ (When it No Longer Matters Where you Live,1998: p. 77)
}

With the changing social and political circumstances in Nigeria, the emphasis on social milieu has shifted increasingly away from satirizing unemployment, bribery and corruption towards addressing a transcendental homelessness in this poem: "There's no one so hurt at home/Who forgets the pain outside". The signification of exile as the chosen theme in the poem is subtly portrayed on the basis of the Derridian differance, and it is linked to the individual's struggle for physical and spiritual survival under an oppressive military regime. Ogaga Ifowodo's The Oil Lamp shares the same thematic preoccupation of alienation with Ojaide's When it no longer Matters Where you Live. Nevertheless, Ifowodo's poetry contains bitterness and outbursts of anger which detail the horrors and miseries which describe the dangers of living in Nigeria during General Sani Abacha's regime. The poem aptly explains Ifowodo's running into exile as a necessity:

What are the things that grow here?

Those that grow from stone, lacking

Life and root flesh and water

Things cut as caps

For the baldness of stone...

And how do children grow here?

Out of wombs whipped with want

And desire, they burst forth, to be

Tough like street leather, sweet and hardy

Like sugarcane, to learn love in safe time.

Here, we will walk the street

where laughter is hidden in deep places

and stores cannot shut their doors

choked with hearts that bleed from gathered wounds

and you will see nothing can grow here, but agony.

(The Oil Lamp: 2005: p. 45)

The poem does not hesitate to bring forth a reality of anomie that is grounded in the nightmarish Nigerian political landscape, and which resoundingly negates the possibility of the poet staying in Nigeria. The enormity of this pervading anomie is reiterated 
on the basis of Derrida's differance mode, and rendered in the declamatory tone of the poem, heightening a sense of transcendental hopelessness: "Choked with hearts that bleed from gathered wounds/And you will see nothing can grow here, but agony”. Satire in the poem not only provokes anguished questioning of Nigeria's ability to sustain good governance that could guarantee safety and well-being of its citizens, but also probes the country's deterioration into a ridiculous pariah, where all manner of incongruities, atrocities and human degradations take place freely.

\section{Conclusion}

In evaluating the use of language to articulate the social, cultural and political concerns in contemporary Nigeria, this paper has succinctly examined how the selected poets have used satire in poetry, in order to criticize social ills in contemporary Nigeria. In the selected poems satire is expressed using proverbs, aphorism and irony which serve as artistic elements that are grounded in African tradition and culture, satire in short allows the poet to air social criticism and express social engagement. The poetics of the selected poems in this paper is influenced by the oral tradition, "which often adapt the story line of myths and traditional dramatic idiom to interpret contemporary life" (Bamikunle, I992, p. 50). This appropriation of the African tradition/culture is borne out of what can be essentially described as the selected poets' "recognition of the functions which verbal art forms perform in the society" (Bodunde, I992, p. 25). As such, their profuse use of irony, witticism and proverbs, which I show is sufficiently rooted in the African orature and Nigerian social landscape, serves as the literary space which the selected poems have literally and metaphorically commented upon.

As George Test has reiterated, satire by its very nature challenges the audience to make a link between the work and the context in which it finds expression (Test, I99I, p. 32). In this vein, the selected poems in this paper respond to the the injustices of the military, moral vices, the dependency syndrome and other social ills observed in the Nigerian social milieu. Suffice to say that the paper has demonstrated how the selected Nigerian contemporary poets have harnessed the elements of tradition/culture and social commitment by the means of satire, to criticize the social ills in Nigeria.

The poets, whose poems have been discussed in this essay have pointedly utilized, Derrida's 'differance' to convincingly articulate 'metaphors of Nigeria', in describing the tragedy of missed opportunities and broken promises. A variety of poetic devices including irony, sarcasm, proverbs, humour and metaphor, have been employed by the selected poets, to enlist the reader as a collaborator in their works. The poets have used their poetics to create an awareness of the impact of corruption, mismanagement and profligacy of successive Nigerian governments; to articulate abhorrence of the grinding poverty and unemployment in contemporary Nigeria; to emphasize the impassioned explication of the predatory attitudes of the clergy in Nigeria, and finally to repudiate the growth of moral vice in the country.

In sum, confronting the inevitable choice between the often opposed demands of art and commitment, the contemporary Nigerian poets, whose works have been ex- 
amined in this paper have chosen to fall back on the possibilities offered by the social, cultural and political circumstances prevalent in the country, where the requirements of aesthetic satisfaction and social relevance have been synthesized in such a way that both could be agreeably realized, to criticize social vices considered inimical to the growth of the country.

\section{Acknowledgements}

I sincerely appreciate the prodigious dexterity of Professor Karen King-Aribisala (University of Lagos, Nigeria), in her painstaking nurturing of my path in the art of literary criticism. I am equally grateful to Professor Akachi Adimora-Ezeigbo (University of Lagos, Nigeria), for her sustained, quintessential discourse on satire over the years. I am eternally grateful to Mary-Juliet Akingbe, whose remarkable comment on the earlier draft has unambiguously sharpened the locus of this paper, and for her unflagging appraisal of my writing always. Finally, I wish to reiterate my profound gratitude to the Afrika Focus journal, for providing me with a convenient platform which allowed me to articulate the inherent satiric nuances of contemporary Nigerian poetry.

\section{References}

Achebe, C. (1958). Things Fall Apart. London: Heinemann Educational Books.

Akingbe, N. (20II). Social Protest and the Literary Imagination in Nigerian Novels. Germany: Lap Lambert Academic Publishing.

Aluko, T.M. (1967). One Man, One Wife. London: Heinemann Educational Books.

Bamikunle, A. (1992). Niyi Osundare's Poetry \& the Yoruba Oral Artistic Tradition. African Literature Today, (18), pp. 49-6r.

Bodunde, C. (I992). Oral Traditions \& Modern Poetry: Okot p'Bitek's Song of Lawino \& Okigbo's Labyrinths. African Literature Today, I8, pp. 24-34.

Chinweizu. (1977). Energy Crisis and Other Poems. New York: Nok Publishers.

Darah, G.G.(2005). Battles of Songs: Udje Tradition of the Urhobo. Lagos: Malt House Press. (I988). Literary Development in Nigeria. In Ogunbiyi, Y.(Ed.) Perspectives on Nigerian Literature:1700 to the present, Vol. I, pp. I-9. Lagos: Guardian Publications.

Derrida, J. (1972). Structure, Sign and Play in the Discourse of the Human Sciences. In Macksey, R. and Donato E. (Eds.). The Structuralist Controversy: The Languages of Criticism and the Science of Man, p. I46. Baltimore: John Hopkins University Press.

(1973). Differance in Speech and Phenomena and other essays on Husserl's Theory of Signs. trans. David B. Allison, p. I3r. Evanston: Northwestern University Press.

Ekwensi, C. (1954). People of the city. London: Andre Dakers.

Emenyonu, E. (1988). Pita Nwana. In Ogunbiyi Y. (Ed.), Perspectives on Nigerian Literature: 1700 to the present, Vol.2, pp. 9-I3. Lagos: Guardian Publications.

(1988). Cyprian Ekwensi. In Ogunbiyi, Y. (Ed.), Perspectives on Nigerian Literature: 1700 to the present. Vol. 2, pp. 20-27. Lagos: Guardian Publications.

Fagunwa, D.O. (1939). Ogboju Ode Ninu Igbo Irunmole. Lagos: Nelson.

(I949). Igbo Olodumare. Lagos: Nelson.

(1949). Ireke Onibudo. Lagos: Nelson.

(1954). Irinkerindo Ninu Igbo Elegbeje. Lagos:Nelson. 
(I961). Adiitu Olodumare. Lagos: Nelson.

Fatoba, F. (1984). Petals of Thought. London: New Beacon Books. (200I). They said I abused the Government. Ibadan: Sterling-Horden Publishers.

Hayford, C. J.E. (IgII) (reissued,I969). Ethiopia Unbound. London: Frank Cass.

Henshaw, J.E. (1945). This is our Chance. London: University of London Press.

Hoggart, R. (1957). The Uses of Literacy. Harmondsworth: Penguin.

Ifowodo, O. (2005). The Oil Lamp. Trenton, NJ: Africa World Press.

Johnson, S. (I92I). The History Of the Yorubas:From the Earliest Times to the Beginnings of the British Protectorate. London: Routledge.

Njogu, K. (200I). Kimondo, Satire, and Political Dialogue: Electioneeering through Versification. Research in African Literatures, 32.(I), pp. I-I3.

Nwachukwu-Agbada, J.O.J. (I9gI). The Language of Post-war Nigerian Poetry of English Expression. African Literature Today, 17, pp. 65-174.

Nwana, P. (1935). Omenuko. London: Atlantis Press.

Obeng, R.E. (1943). Eighteenpence. Ilfracombe: Stockwell.

Olaniyan, T. (1988). Timothy Aluko. In Ogunbiyi Y. (Ed.), Perspectives On Nigerian Literature:1700 to the Present, Vol. 2, pp. 48-53. Lagos: Guardian Publications.

Ofeimun, O. (1980). The Poet Lied. London: Longman.

Ohaeto, E. (I986). Song of a Traveller. Awka: Towncrier Publications.

Ojaide, T. (1998). When it No longer Matters Where you live. Calabar: University of Calabar Press.

Okam, H.H. (I99I). The Novelist as Historian: Yambo Ouologuem's Le Devoir de Violence Revisted. In Ikonne, C., Oko. E. and P. Onwudinjo (Eds.), African Literature and African Historical Experiences, p. 54, Ibadan: Heinemann Educational Books.

Okunoye, O. (20II). Writing resistance: Dissidence and visions of healing in Nigerian poetry of the military era. Tydskrif vir Letterkunde, 48, (I), pp. 64-85.

Olabimtan, A. (1988). Daniel Fagunwa. In Ogunbiyi Y. (Ed.). Perspectives On Nigerian Literature: 1700 to the Present, Vol.2, pp. I4-I9. Lagos: Guardian Publications.

Osundare, N. (1984). Village Voices. Ibadan: Evans (Nigeria).

Osha, S. (1998). Writing in a Continent Under Siege. Research in African Literatures. 29, (I), p. 176.

Peters, L. (1999). He Walks Alone. In Soyinka W. (Ed.). Poems of Black Africa. London: Heinemann Educational Books.

Sekyi, K. (1974). The Blinkards. Ghana. Heinemann Educational Books.

Test, G.A.(I99I). Satire: Spirit and Art. Tampa: University of South Florida Press.

Udechukwu, O. (1978). In Omabe. (Nsukka) vol. 28.

Wa Thiong'o, N. (1972). Homecoming. London: Heinemann Educational Books.

Yahaya, I.Y. (1988). The Development Of Hausa Literature. In Ogunbiyi Y. (Ed.). Perspectives on Nigerian Literature: 1700 to the present. Vol.I, pp. IO-2I. Lagos: Guardian Publications.

Yahaya, I.Y., Aminu Kano. (I988). In Ogunbiyi Y.(Ed.) Perspectives on Nigerian Literature: 1700 to the present. Vol.2, pp. 85-9I. Lagos: Guardian Publications. 